\title{
The ubiquitin ligase RNF181 stabilizes ERa and modulates breast cancer progression
}

\author{
Jian Zhu $\mathbb{I}^{1} \cdot$ Xin $\mathrm{Li}^{2} \cdot$ Peng $\mathrm{Su}^{3} \cdot$ Min Xue ${ }^{2} \cdot$ Yifeng Zang ${ }^{1} \cdot$ Yinlu Ding $\mathbb{B}^{1}$
}

Received: 3 February 2020 / Revised: 17 August 2020 / Accepted: 10 September 2020 / Published online: 24 September 2020

(c) The Author(s) 2020. This article is published with open access

\begin{abstract}
ER $\alpha$ positive breast cancer accounts for $70 \%$ of breast malignancies. Compared with ER $\alpha$ negative types, ER $\alpha$ positive breast cancer could be effective controlled by endocrine therapy. However, more than half of the patients will develop endocrine resistance, making it an important clinical issue for breast cancer therapy. Endocrine resistance might be caused by multiple alternations, including the components of ER $\alpha$ signaling, during tumor progression. Thus, it is urgent and necessary to uncover the molecular mechanisms that controls ER $\alpha$ expression and stability to improve breast cancer therapeutics. In our current study, we identifies that the ubiquitin ligase RNF181 stabilizes ER $\alpha$ and facilitates breast cancer progression. The expression of RNF181 is correlated with ER $\alpha$ level in human breast tumors and relates to poor survival in endocrine-treated patients. RNF181 depletion inhibits breast cancer progression in vivo and in vitro, reduces ER $\alpha$ protein level and its target gene expression, such as PS2 and GREB1. Unbiased RNA sequencing analysis indicates RNF181 is necessary for ER $\alpha$ signature gene expression in whole genomic level. Immuno-precipitation assays indicate that RNF181 associates with ER $\alpha$ and promotes its stability possibly via inducing ER $\alpha$ K63-linked poly-ubiquitination. In conclusion, our data implicate a non-genomic mechanism by RNF181 via stabilizing ER $\alpha$ protein controls ER $\alpha$ target gene expression linked to breast cancer progression.
\end{abstract}

These authors contributed equally: Jian Zhu, Xin Li

Supplementary information The online version of this article (https:// doi.org/10.1038/s41388-020-01464-z) contains supplementary material, which is available to authorized users.

Jian Zhu

zhujian1204@yahoo.com

$\triangle$ Yinlu Ding

dingyinlu@126.com

1 Department of general surgery, the Second Hospital, Cheeloo College of Medicine, Shandong University, 250033 Jinan, China

2 Xinxiang Key Laboratory of Tumor Migration, Invasion and Precision Medicine, School of Laboratory Medicine, Henan Collaborative Innovation Center of Molecular Diagnosis and Laboratory Medicine, Xinxiang Medical University, Xinxiang 453003, Henan Province, P.R. China

3 Department of Pathology, Qilu Hospital, Cheeloo College of Medicine, Shandong University, 250033 Jinan, China

\section{Introduction}

Breast cancer is the most common female malignancy worldwide [1]. According to latest cancer epidemiological report, more than 1.6 million breast cancer cases are diagnosed each year, which account for about $20 \%$ of all women malignancies [2]. Based on the clinical-pathological classification, breast cancers are grouped as Endocrine receptorpositive type (positive for estrogen receptors or progesterone receptors), HER2-positive type, and triple negative type (TBNC) (negative for estrogen receptors, progesterone receptors, and HER2) [3]. Compared with HER2 positive and triple negative breast cancer subtypes, ER $\alpha$ positive breast cancer patients show a significant priority in prognosis and could benefit from endocrine therapy [4]. However, approximately half of the patients will develop endocrine resistance overtime, making it a major challenge for both clinics and basic researches [5-7]. Thus, the insight into the detailed mechanisms, which control the ER $\alpha$ signaling activity, is critical for developing novel therapeutics for breast cancer.

The relation between ER $\alpha$ and breast cancer was discovered 30 years ago [8]. ER $\alpha$ belongs to the member of the 
nuclear receptor superfamily and composed of three functional domains: a DNA-binding domain (DBD), a ligandbinding domain (LBD) and one transcriptional activation domain (AF1) [9]. When ER $\alpha$ is activated by estrogen, it trans-locates into the nucleus, forms the hemo-dimers and binds to the promoter regions of ER $\alpha$ target genes, which subsequently promotes breast cancer initiation and progression. Clinically, ER $\alpha$ expression level correlates with breast cancer risk and two-thirds of breast cancers have elevated level of ER $\alpha$. The selective estrogen receptor modulators, such as tamoxifen, share the structure similarity with estradiol, which bind to ER $\alpha$ protein and block its transcriptional activity in breast cancer $[10,11]$.

Although there are several possible and confirmed mechanisms for endocrine resistance, the detailed mechanisms are still not clear. Besides a small proportion of breast cancers, which lose ER $\alpha$ expression during endocrine therapy, most of endocrine resistant breast tumors still maintain ER $\alpha$ expression [12]. Several studies pointed out that the co-activators of ER $\alpha$ signaling coupled with ER $\alpha$ modifications contribute to enhanced ER $\alpha$ signaling and endocrine resistance [13-15]. Thus, understanding the ubiquitin-proteasome system of $\mathrm{ER} \alpha$ protein, including numerous E3 ubiquitin ligases, coupled with modulating ER $\alpha$ protein stability could be a promising strategy for breast cancer therapeutics, especially for endocrine resistant patients.

There are approximately more than 700 E3 ubiquitin ligases, which could be grouped into four families according to the functional domains: HECT type, RING type, Ubox type, and PHD-finger type [16]. Among these groups, the RING finger E3 ligase group is the biggest, while the function is largely unknown. Our previous studies identified several RING proteins, which were elevated in breast cancer and modulates cancer progression [17, 18]. In our current study, we implicate RNF181 (RING Finger Protein 181) in modulating ER $\alpha$ protein stability and breast cancer progression. RNF181 associates with AF1 domain of ER $\alpha$ via its RING domain and prolongs ER $\alpha$ stability, which subsequently enhances ER $\alpha$ target gene expression and breast cancer cell proliferation.

\section{Results}

\section{RNF181 is elevated in breast cancer and correlates with poor survival in endocrine therapy patients}

We first investigate the possible role of RNF181 from public available database. From the ONCOMINE database, we observe that RNF181 is elevated in breast cancer compared with normal breast tissue in multiple clinical cohorts (https://www.oncomine.org/resource/login.html) (Fig. 1a-c).
The survival data analysis shows that RNF181 is correlated with shorter progression-free survival in all breast cancer patients (Fig. 1d). In the subtype analysis, RNF181 correlates with poor survival in Luminal A type and Luminal B type breast cancer, but not with HER2 type and triple negative breast cancer types (Fig. 1e-h). We further analyze the prognostic effect of RNF181 in endocrine-treated patients. Three independent clinical cohorts show that RNF181 correlates with poor survival in breast cancer patients with endocrine therapy (Fig. 1i-k).

\section{RNF181 depletion inhibits breast cancer progression in vivo and in vitro}

In order to investigate the impact of RNF181 on breast cancer phenotypes, we deplete RNF181 in breast cancer cells (Fig. 2a). WST assay shows that RNF181 depletion significantly decreases breast cancer cell proliferation in MCF-7 and T47D cells (Fig. 2b, c). Clone formation assay shows that RNF181 depletion dramatically inhibits the clone formation capacity in MCF-7 cells (Fig. 2d). Beside, the wound-healing assay shows that RNF181 knockdown decreases the wound closure speed in MCF-7 cells (Fig. 2e). Then we further investigate the role of RNF181 in vivo by xenograft mice model. Our data show that RNF181 depletion inhibits the tumor growth speed in vivo (Fig. $2 \mathrm{f}-\mathrm{h}$ ).

\section{RNF181 correlates with ERa protein level in human samples and controls ERa target gene expression in whole genomic scale}

In order to investigate the correlation between RNF181 expression and breast cancer molecular biomarkers, 120 breast cancer tissues are collected for immunohistochemistry (IHC) analysis. We examine the protein expression levels including RNF181, ER $\alpha$, PR, and HER2 (Fig. 3a). Besides, the pathological grade and lymph node metastasis data are also collected. The IHC analysis implicate that RNF181 expression correlates with ER $\alpha$ protein level, but no correlation with other with other molecular and clinical characteristics (Fig. 3b). In order to approach the function of RNF181 in breast cancer cells in an unbiased way, we deplete RNF181 in MCF-7 cells for the whole genomic expression analysis. The bioinformatics analysis shows that RNF181 depletion inhibits several signaling, including $\mathrm{ER} \alpha$ signaling and angiogenesis signaling, while activates several pathways, such as NFKB signaling and cell death signaling (Fig. 3c). Since ER $\alpha$ signaling is predominant in ER $\alpha$ positive breast cancer cells, we further investigates the change of ER $\alpha$ target gene in whole genomic scale. The heat-map shows RNF181 depletion significantly decrease a group of ER $\alpha$ genes, including PS2 and GREB1 (Fig. 3d). 
A

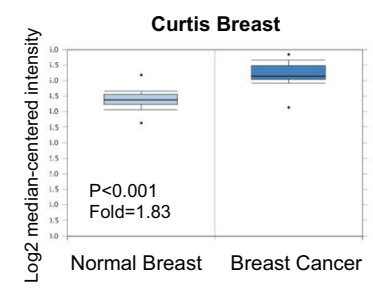

B

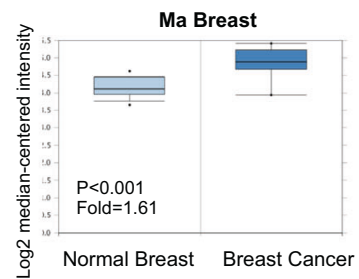

C

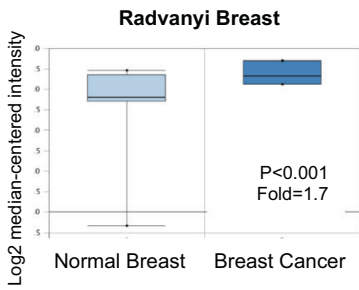

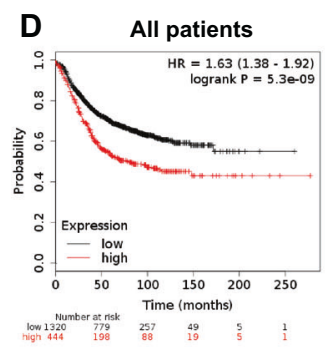
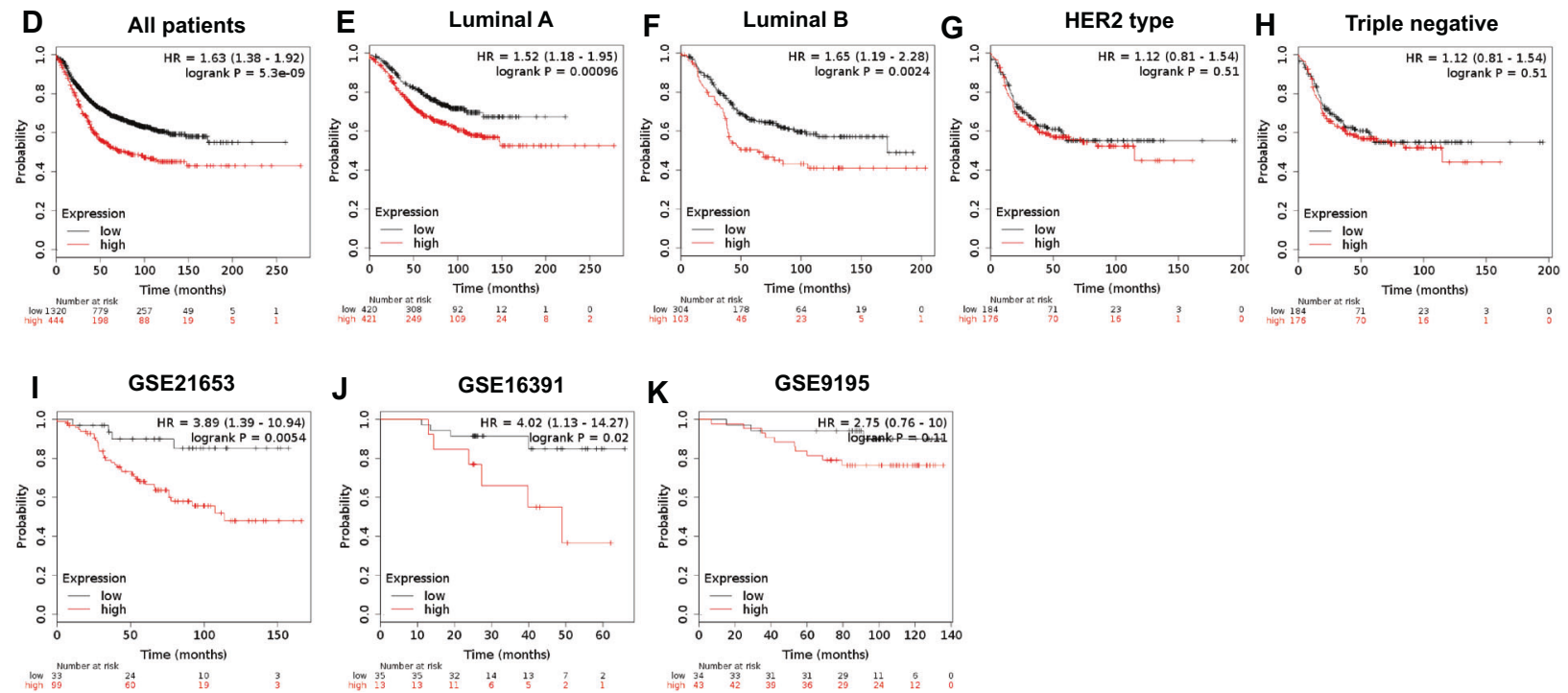

Fig. 1 RNF181 is elevated in breast cancer and correlates with poor survival in endocrine therapy patients. a-c RNF181 is elevated in breast cancer compared with normal breast tissue in multiple clinical cohorts (https://www.oncomine.org). d RNF181 expression is correlated with poor survival in breast cancer patients (https://kmplot. com). e RNF181 expression is correlated with poor survival in Luminal A type breast cancer patients (https://kmplot.com). f RNF181

expression is correlated with poor survival in Luminal B type breast cancer patients (https://kmplot.com). g There is no statistical correlation between RNF18 and survival in HER 2 type breast cancer patients (https://kmplot.com). h There is no statistical correlation between RNF181 and survival in HER2 type breast cancer patients (https:// kmplot.com). i-k RNF181 correlates with poor endocrine therapy outcome in multiple clinical cohorts (https://kmplot.com).

\section{RNF181 facilitates ERa signaling in breast cancer cells}

We utilize two independent siRNAs to carry out the experiments. The immuno-bloting shows that RNF181 depletion significantly decreases ER $\alpha$ proein level (Fig. 4a). The QPCR assay shows that RNF181 depletion decreases the expression of ER $\alpha$ target genes, including GREB1 and PS2 (Fig. 4b). We further test RNF181 effect on ER $\alpha$ signaling in both vehicle and E2-treated conditions. RNF181 depletion could decrease ER $\alpha$ protein level in vehicle and E2-treated conditions in both MCF-7 and T47D cells (Fig. 4c, d). Consistently, RNF181 depletion could dramatically decrease ER $\alpha$ target gene expression in MCF-7 and T47D cells, including PS2, GREB1, and PDZK1 (Fig. $4 \mathrm{e}, \mathrm{f}$ ). In order to determine if RNF181 knockdown could affect ER $\alpha$ transcriptional activity, we measure estrogen response element (ERE) luciferase activity in both MCF-7 and T47D cells. The luciferase assay shows that RNF181 depletion decreases ERE luciferase activity in both MCF-7 and T47D cells (Fig. 4g, h). We further investigated the role of RNF181 in ER signaling under tamoxifen-treated conditions. RNF181 depletion could decrease ER $\alpha$ target gene expression in MCF-7 under anti-estrogen condition, including GREB and PS2 (Fig. 4i). Besides, the cell viability assay showed that RNF181 depletion could sensitize tamoxifen inhibition effect in MCF-7 cells (Fig. 4h). We further utilized siRNA, which targeted the UTR regions of RNF181. The data showed that three independent siRNAs could effectively inhibited ER $\alpha$ protein level, ER $\alpha$ target genes expression, and ERE luciferase activity in MCF-7 cells (Supplementary fig. 1A-E). Further rescue experiments showed that RNF181 overexpression could rescue MCF-7 cell proliferation, migration and clone formation, which were inhibited by RNF181 UTR siRNAs (Supplementary fig. 1F-H). Besides, we also validated the effect of RNF181 via siRNAs provided from Depmap database. The data also showed that RNF181 depletion inhibited ER $\alpha$ signaling, breast cancer cell proliferation, migration, and clone formation in MCF-7 cells (Supplementary fig. 2). 
A
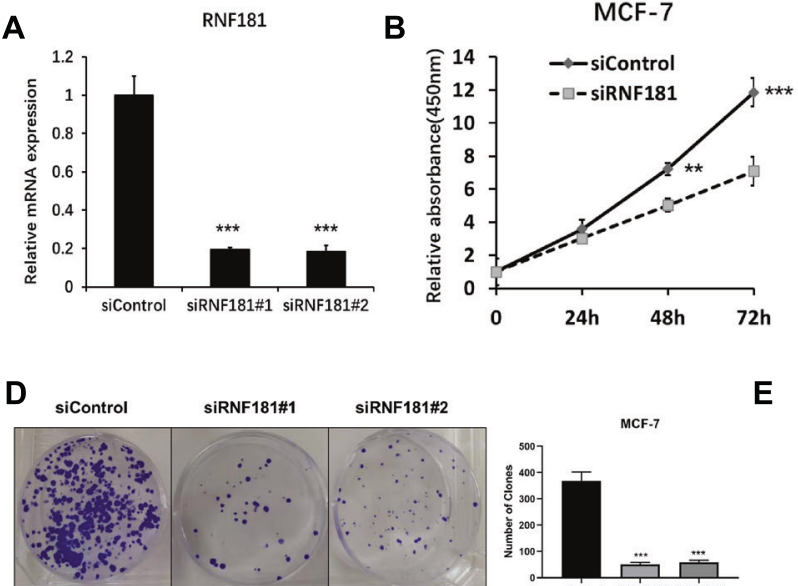

D
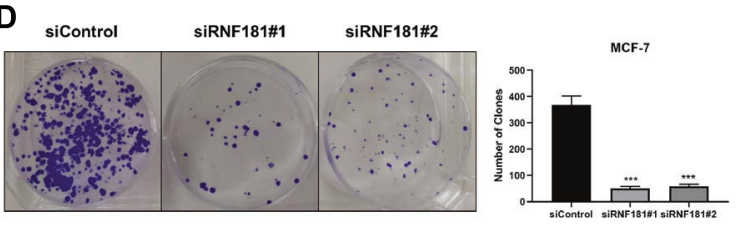

$\mathbf{F}$

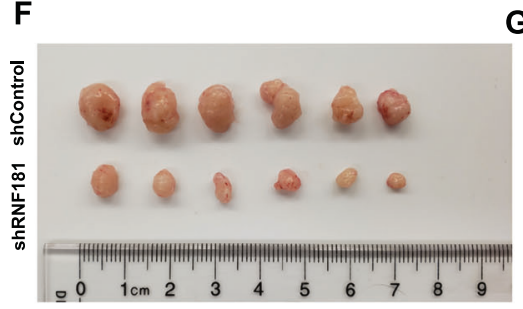

C

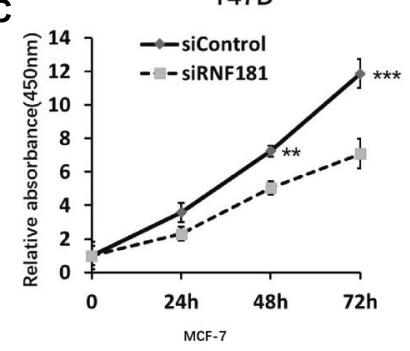

E

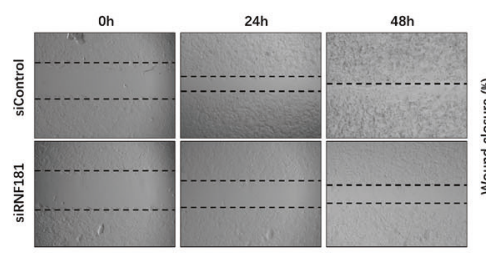

H
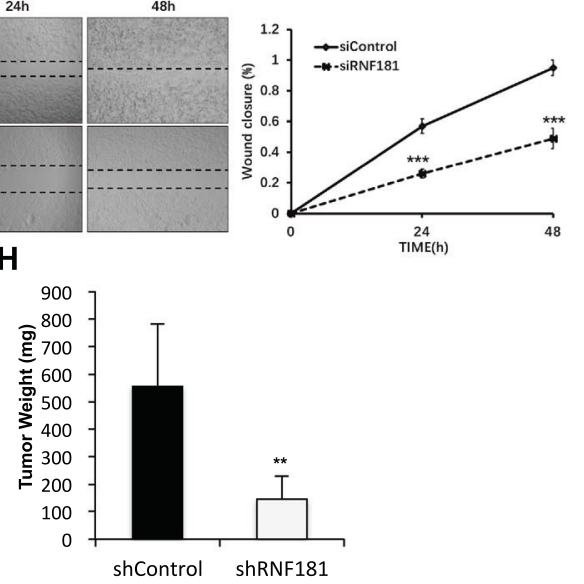

Fig. 2 RNF181 depletion inhibits breast cancer progression in vivo and in vitro. a RNF181 knockdown efficiency in breast cancer cell. MCF-7 cells was transfected with siControl or siRNF181. The RNF181 mRNA levels were measured by Q-PCR. $* P<0.05$; $* *<$ $0.01 ; * * * P<0.001$ for target gene expression comparison. $\mathbf{b}$ and $\mathbf{c}$ Depletion of RNF181 inhibits the proliferation of breast cancer cells. MCF-7 and T47D cells were transfected with siControl or siRNF181. After $24 \mathrm{~h}$, the assay was CCK8 used to determine the cellar metabolic activity at indicated time points after infection. Experiments were done in triplicates. $* P<0.05$; $* * P<0.01 ; * * * P<0.001$ for cell growth comparison. d Clone formation assay of MCF-7 cells transfected with indicated $50 \mathrm{nM}$ RNF181 siRNA (mix of \#1 and \#2) or $50 \mathrm{nM}$ control siRNA. Quantification of clone formation is shown at the indicated time points. Data are presented as $\pm \mathrm{SD}$. $* * P<0.01, * * * P<0.001$

\section{RNF181 associates with ERa and modulates ERa stability}

We further investigate the localization of RNF181 and ER $\alpha$ in breast cancer cells. The immuno-staining shows that ER $\alpha$ is mainly located in the nuclear, while RNF181 locates both in the cytosol and nuclear (Fig. 5a). The endogenous immuno-precipitation shows that RNF181 could interact with ER $\alpha$ in MCF-7 cells (Fig. 5b). Since RNF181 could associate with $\mathrm{ER} \alpha$ in breast cancer cells, we further investigate the biological effect of such interaction. Since ER $\alpha$ could regulate its own expression, making it difficult to distinguish direct effects of RNF181 on ER $\alpha$ mRNA or protein levels in the cell line. We utilize HEKC293 cells to investigate the mechanism. Co-transfection of ER $\alpha$ and RNF181 in HEK293 cells shows that RNF181 could increase ER $\alpha$ protein level, which effect could be minimized with the presence of the proteasome inhibitor MG132 (student's $t$ test). e Wound-healing assay of MCF-7 cells were transfected with siControl or siRNF181. Quantification of wound closure at the indicated time points. Data are presented as \pm SD. $* * P<0.01$, $* * * P<0.001$. f-h MCF-7 cells were stably transfected with lentivirus carrying scrambe shRNA or RNF181 shRNA. Female NOD scid gamma (NSG) mice were estrogen-supplemented by implantation of slow-release $17 \beta$-estradiol pellets $(0.72 \mathrm{mg} / 90$-d release; Innovative Research of America) one day before MCF-7 tumor cell injection into the mammary fat pad $\left(2 \times 10^{6} \mathrm{MCF}-7\right.$ cells suspended in $100 \mathrm{ul}$ Matrigel solution). MCF-7 tumor xenografts were measured every 3 days and the tumor volume were calculated by length $\times$ width $^{2} / 2$. The mice were sacrificed at 6 weeks after transplant. The tumor growth curve, tumor weight, and photograph were shown in figure $\mathbf{f}, \mathbf{g}$ and $\mathbf{h}$ respectively.

(Fig. 5c). The protein half-life assay shows that RNF181 could increase the protein stability of ER $\alpha$ (Fig. 5d).

\section{RNF181 associates with AF1 domain of ERa through its RING domain}

We further characterize the interaction domains between RNF181 and ER $\alpha$. ER $\alpha$ is composed of three functional domains: AF1 domain, DNA-binding domain, and AF2 domain, while RNF181 contains one functional RING domain (76aa-117aa). We make the ER $\alpha$ variants (AF1 domain, $\mathrm{AF} 1+\mathrm{DBD}$ domains, $\mathrm{AF} 2$ domain and $\mathrm{AF} 2+\mathrm{DBD}$ domains) and RNF181 variants (N-terminal: 1-76 aa; RING domain: 76-117 aa; C-terminal: 117-153 aa) (Fig. 6a). Immuno-precipitation implicates that the AF1 domain of $\mathrm{ER} \alpha$ is required for its interaction with RNF181 (Fig. 6b, c), while the RING domain of RNF181 is required for its interaction with ER $\alpha$ (Fig. 6d). However, co-transfection of ER $\alpha$ with 


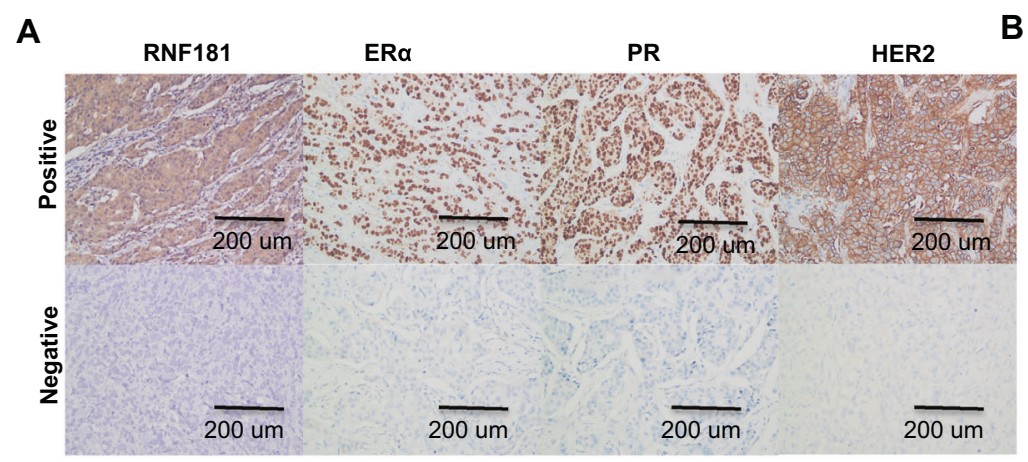

\begin{tabular}{|c|c|c|c|c|}
\hline \multirow{2}{*}{\multicolumn{2}{|c|}{$\begin{array}{l}\text { Clinical and molecular } \\
\text { characteristics (Cases) }\end{array}$}} & \multicolumn{3}{|c|}{ RNF181 } \\
\hline & & + & - & $P$ value \\
\hline \multirow{2}{*}{ ER $a$} & + & 50 & 24 & \multirow{2}{*}{0.03} \\
\hline & - & 21 & 25 & \\
\hline \multirow{2}{*}{ PR } & + & 33 & 18 & \multirow{2}{*}{0.28} \\
\hline & - & 38 & 31 & \\
\hline \multirow{2}{*}{ HER2 } & + & 19 & 18 & \multirow{2}{*}{0.18} \\
\hline & - & 52 & 31 & \\
\hline \multirow{2}{*}{$\begin{array}{l}\text { lymph node } \\
\text { metastasis }\end{array}$} & + & 34 & 24 & \multirow{2}{*}{0.90} \\
\hline & - & 37 & 25 & \\
\hline \multirow{3}{*}{ pathological grade } & low & 3 & 0 & \multirow{3}{*}{0.06} \\
\hline & medium & 41 & 21 & \\
\hline & High & 27 & 28 & \\
\hline
\end{tabular}

C

\begin{tabular}{|c|c|}
\hline Suppressed Pathways by siRNF181 & Activated Pathways by siRNF181 \\
\hline Estrogen-mediated S-phase Entry & Focal adhesion \\
\hline Positive regulation of cell migration & Hippo signaling pathway \\
\hline Angiogenesis & NF-KB Signaling \\
\hline Small cell lung cancer signaling & Bacterial invasion of epithelial cells \\
\hline Thyroid cancer signaling & Acute Myocardial Infarction \\
\hline Complement System & $\begin{array}{c}\text { Trefoil Factors Initiate Mucosal } \\
\text { Healing }\end{array}$ \\
\hline $\begin{array}{c}\text { Trefoil Factors Initiate Mucosal } \\
\text { Healing }\end{array}$ & \begin{tabular}{c} 
Retinol metabolism \\
\hline Circadian rhythm
\end{tabular} \\
\hline LXR_RXR Activation & Death Receptor Signaling \\
\hline Cholesterol homeostasis & Retinol metabolism \\
\hline
\end{tabular}

Fig. 3 RNF181 correlates with ER $\alpha$ protein level in human samples and controls ER $\alpha$ target gene expression in whole genomic scale. a Examples of positive/negative RNF181, ER $\alpha, \mathrm{PR}$, and HER2 staining in breast tumor samples were shown by $\times 100$ magnification. b RNF181 expression correlates with ER $\alpha$ level in human breast cancer samples. The correlation analysis between RNF181 expression and molecular/clinical characteristics in breast cancer samples was shown. $P$ value $<0.05$ was considered as statistical significance. c Top 10 signaling pathways significantly decreased/

RNF181 variants shows that only the full length of RNF181 could exert its stabilization function on ER $\alpha$ protein (Fig. 6e).

\section{RNF181 facilitates K63-linked poly-ubiquitination of ERa}

Since RNF181 is a putative E3 ubiquitin ligase, we further investigate the role of RNF181 on ER $\alpha$ ubiquitination. The ubiquitination-based immuno-precipitation shows that RNF181 could inhibit ER $\alpha$ overall poly-ubiquitination (Fig. 7a). Since K48-linked ubiquitination is the most common degradation manner, we examine the RNF181 effect on K48-linked ubiquitination of ER $\alpha$, which implicates that RNF181 could inhibit K48-linked ubiquitination of ER $\alpha$ (Fig. 7b). However, RNF181 could significantly increase K63-linked poly-ubiquitination on $\mathrm{ER} \alpha$ protein
D

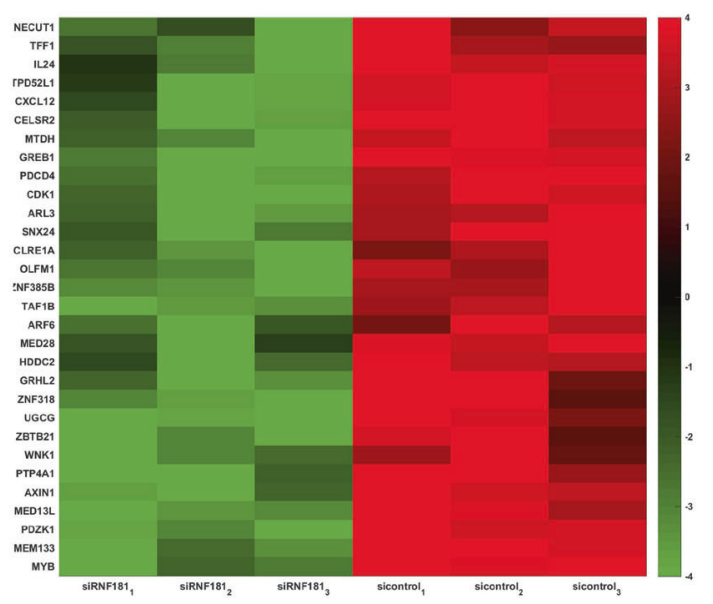

increased by RNF181 depletion in MCF7 cells. The pathwayenrichment analysis was used by the threshold $P<0.001$ and fold change $>2$ to derive regulated genes. RNF181 was depleted by siRNA (mix of siRNF181 \#1 and siRNF181 \#2) or treated with siControl. After $48 \mathrm{~h}$, the whole mRNA was extracted for RNA sequence analysis. The siControl and siRNF181 were done in triplicates. d The heat-map graph shows the ER $\alpha$ regulating genes, which is significantly inhibited by RNF181 depletion in MCF-7 cells.

(Fig. 7c). We further investigated ER $\alpha$ poly-ubiquitination in MCF-7 cells. Endogenous ER $\alpha$ pull down assay together with immuno-bloting for K48 and K63-linked ubiquitin signals showed that RNF181 depletion could significantly increase K48-linked ubiquitination of endogenous ER $\alpha$, while decrease K63-linked ubiquitination of endogenous ER $\alpha$ in MCF-7 cells (Fig. 7d, e). In order to decide which is the functional domain for RNF181 to modulate ER $\alpha$ ubiquitination, RNF181 full length or deletion constructs (N-terminal: 1-76 aa; RING domain: 76-117 aa; C-terminal: 117-153 aa) together with ER $\alpha$ are transfected into HEK293 cells. Interestingly, only full length of RNF181 could inhibit K48-linked ER $\alpha$ ubiquitination and promote K63-linked ER $\alpha$ ubiquitination (Fig. 7f, g). This indicates all the domains of RNF181 is involved in modulate ER $\alpha$ ubiquitination. 

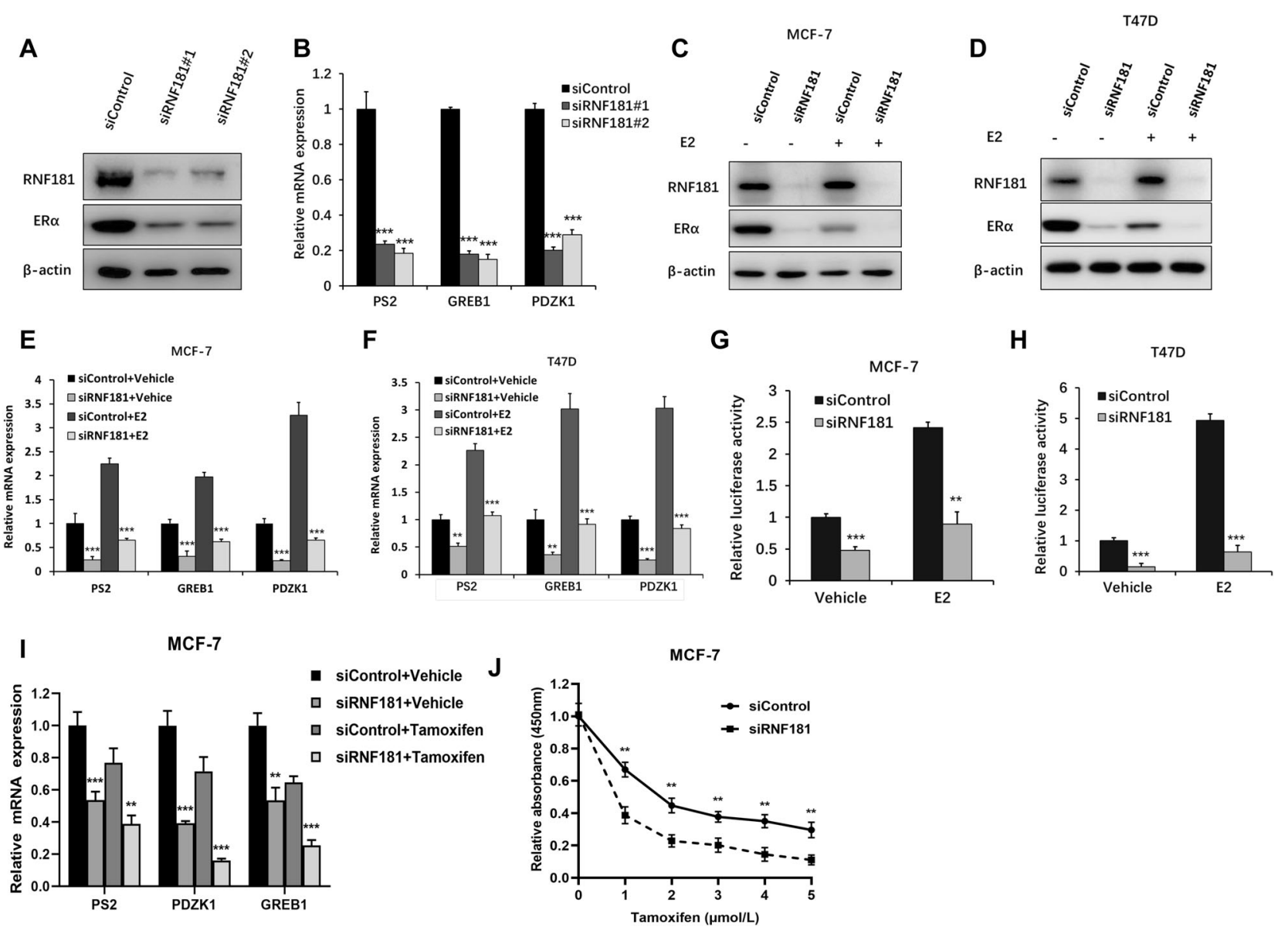

Fig. 4 RNF181 facilitates ER $\alpha$ signaling in breast cancer cells. a RNF181 consumption decreased ER $\alpha$ protein levels in MCF-7 cells. MCF-7 cells were transfected with siControl or siRNF181. After $48 \mathrm{~h}$, cells were harvested for western blot analysis. RNF181 and ER $\alpha$ protein levels were determined by Western blot. Actin was used as internal control. b RNF181 consumption decreased ER $\alpha$ target gene expression in MCF-7 cells. MCF-7 cells were transfected with siControl or siRNF181. After $48 \mathrm{~h}$, total RNA was extracted for gene expression analysis. $* P<0.05 ; * * P<0.01 ; * * * P<0.001$ for target gene expression comparison. c RNF181 depletion decreases ER $\alpha$ protein levels in both vehicle and E2-treated conditions in MCF-7 cells. MCF-7 cells were transfected with siRNF181 or siControl. After $48 \mathrm{~h}$, cells were treated with either ethanol or $10 \mathrm{nM}$ estradiol for $6 \mathrm{~h}$. RNF181 and ER $\alpha$ protein levels were determined by Western blot analysis. Actin was used as internal control. d RNF181 depletion decreases ER $\alpha$ protein levels in both vehicle and E2-treated conditions in T47D cells. T47D cells were transfected with siRNF181 or siControl. After $48 \mathrm{~h}$, cells were treated with either ethanol or $10 \mathrm{nM}$ estradiol for $6 \mathrm{~h}$. RNF181 and ER $\alpha$ protein levels were determined by Western blot analysis. Actin was used as internal control. e RNF181 depletion decreases ER $\alpha$ target genes in both vehicle and E2-treated conditions in MCF-7 cells. MCF-7 cells were transfected with siRNF181 or siControl. After $48 \mathrm{~h}$, cells were treated with either ethanol or $10 \mathrm{nM}$ estradiol for $6 \mathrm{~h}$. Total RNA was prepared and the expression of the endogenous ER alpha target genes, PS2, GREB1, and PDZK1 were determined by qPCR. Shown are the results from three experiments. $* P<0.05$; $* * P<0.01 ; * * * P<0.001$ for target gene expression comparison. f RNF181 depletion decreases ER $\alpha$ target genes in both vehicle and E2-treated conditions in T47D cells. T47D cells were transfected with siRNF181 or siControl. After $48 \mathrm{~h}$, cells were treated with either ethanol or $10 \mathrm{nM}$ estradiol for $6 \mathrm{~h}$. Total RNA

was prepared and the expression of the endogenous ER alpha target genes, PS2, GREB1, and PDZK1 were determined by qPCR. Shown are the results from three experiments. $* P<0.05$; $* * P<0.01$; $* * * P<$ 0.001 for target gene expression comparison. g RNF181 depletion affects ERE-luciferase activity in MCF-7 cells. MCF-7 cells were transfected with siRNF181 or siControl together with ERE luciferase reporter plasmid. Cells were treated with $10 \mathrm{nM}$ estradiol or vehicle. Luciferase activity was measured $48 \mathrm{~h}$ after transfection. Shown are the results from three experiments. $* P<0.05$; $* * P<0.01$; $* * * P<$ 0.001 for luciferase activity comparison. h RNF181 depletion affects ERE-luciferase activity in T47D cells. T47D cells were transfected with siRNF181 or siControl together with ERE luciferase reporter plasmid. Cells were treated with $10 \mathrm{nM}$ estradiol or vehicle. Luciferase activity was measured $48 \mathrm{~h}$ after transfection. Shown are the results from three experiments. $* P<0.05 ; * * P<0.01 ; * * * P<0.001$ for luciferase activity comparison. i RNF181 depletion decreases ER $\alpha$ target genes in both vehicle and tamoxifen-treated conditions in MCF7 cells. MCF-7 cells were transfected with siRNF181 or siControl. After $48 \mathrm{~h}$, cells were treated with either ethanol or $0.5 \mathrm{uM}$ tamoxifen for $6 \mathrm{~h}$. Total RNA was prepared and the expression of the endogenous ER alpha target genes, PS2, GREB1, and PDZK1 were determined by qPCR. Shown are the results from three experiments. $* P<0.05$; $* * P<$ 0.01 ; $* * * P 0.001$ for target gene expression comparison. $\mathbf{j}$ RNF181 depletion sensitizes tamoxifen inhibition effect in MCF-7 breast cancer cells. MCF-7 cells were transfected with siRNF181 or siControl. After $48 \mathrm{~h}$, cells were plated into 96-well plate, while each well contained 4000 cells. The indicated tamoxifen concentrations were used for $48 \mathrm{~h}$. The numbers of the cells were determined via CCK8 kit for the cellar metabolic activity. Experiments were done in triplicates. $* P<0.05$; $* * P<0.01 ; * * * P<0.001$ for cell growth comparison. 

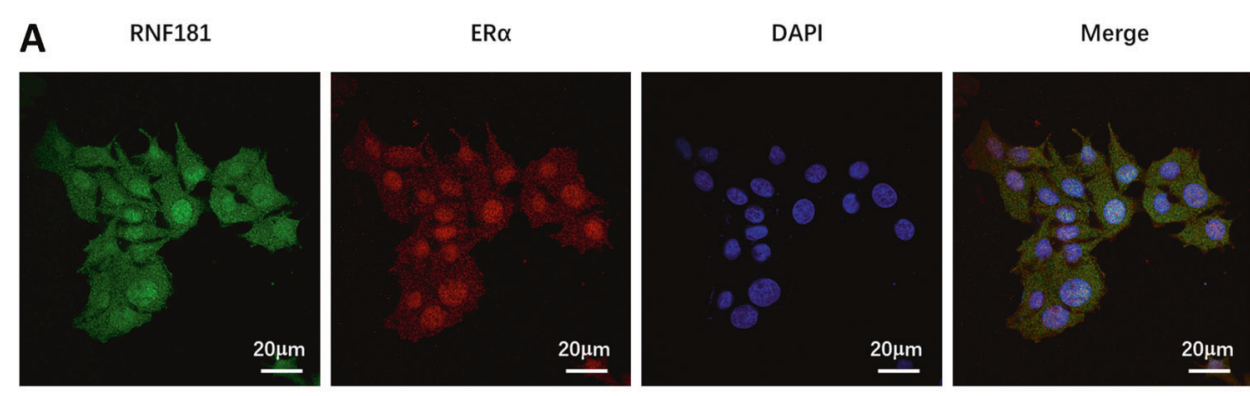

B

WB:ER $\alpha$
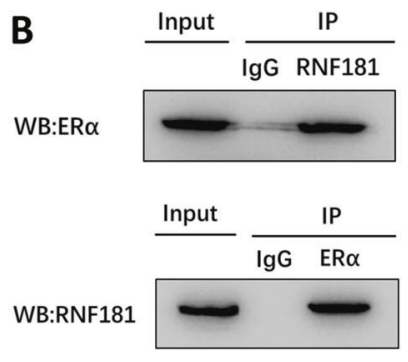

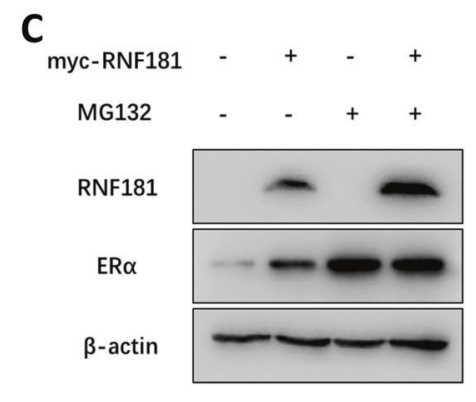

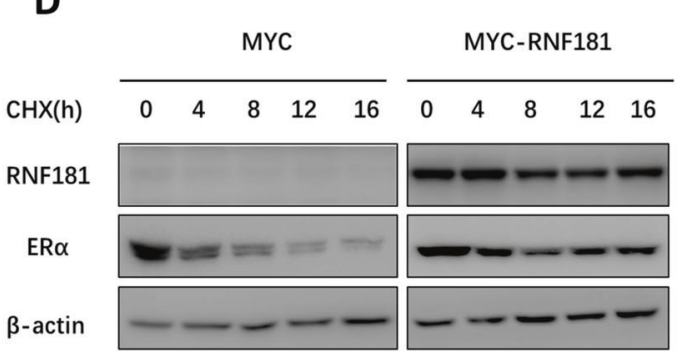

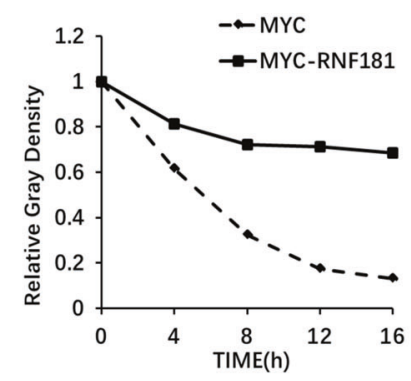

Fig. 5 RNF181 associates with ER $\alpha$ and modulates ER $\alpha$ stability. a Intracellular localization analysis of RNF181 and ER $\alpha$ by immunofluorescence assay. MCF7 cells were cultured in normal medium before fixation. Intracellular localization of RNF181 (green) and ER $\alpha$ (red) were shown. Nuclei (blue) were stained with 4',6-diamidino-2phenylindole (DAPI). b Co-IP assay reveals association between endogenous RNF181 and ER $\alpha$ in MCF7 cells. MCF-7 cells were harvested with RIPA lysis buffer. CO-IP was performed using antibody as indicated. $\mathbf{c}$ In the presence of the proteasome inhibitor MG132, the stabilization effect of RNF181 on ER $\alpha$ did not further increase ER $\alpha$ protein levels. HEK293 cells were transfected with $2 \mu \mathrm{g}$ RNF181 plasmid and $0.5 \mu \mathrm{g}$ Myc-tag or Myc-RNF181 plasmids. After $24 \mathrm{~h}$, cells were treated with $10 \mathrm{uM}$ MG132/vehicle for $6 \mathrm{~h}$. Cell lysates were prepared for Western blot analysis. The results are representative for three independent experiments. d RNF181 increases ER $\alpha$ half-life in HEK293 cells. HEK293 cells were transfected with HA-ER $\alpha$ plasmid and Myc-tag or Myc-ZNF213 plasmids. After $24 \mathrm{~h}$, cells were treated with $100 \mu \mathrm{M}$ cycloheximide/vehicle for indicated times. Cell lysates were prepared for Western blot analysis. The results are representative for three independent experiments. The ER $\alpha$ relative density was measured by Image $\mathbf{J}$ software.

\section{Discussion}

Our study reports that the E3 ubiquitin ligase RNF181 interacts with and stabilizes ER $\alpha$ protein, possibly through K63-linked ubiquitination, which subsequently facilitates $\mathrm{ER} \alpha$ signaling and breast cancer cell progression (Fig. 8). Interestingly, RNF181 could associate with ER $\alpha$ protein level in human breast cancer samples and correlates with poor survival in endocrine therapy patients. Our study provides a novel non-genomic regulation of ER stability control. Based on these data, we can propose that the selective modulators or inhibitors, which control RNF181 activity or expression could a promising strategy for ER $\alpha$ positive breast cancer therapeutics.

The importance of ER $\alpha$ signaling in the carcinogenesis of breast tumor has been identified for more than 30 years, since $70 \%$ of the breast cancers are ER $\alpha$ positive. The risk of breast cancer is also correlated with ER $\alpha$ expression level in breast tissue [19]. High level of ER $\alpha$ expression in breast cancer leads to enhance ER $\alpha$ signaling activity and cell proliferation [20]. Based on the importance of $E R \alpha$, it is a

suitable target for breast cancer therapy. The selective estrogen receptor modulators, including tamoxifen, are standard therapy for ER $\alpha$ positive patients. However, the occurrence of endocrine resistance is a headache problem for breast cancer therapy [21]. Interestingly, most of the endocrine resistant breast tumors still maintain the expression of ER $\alpha$ protein, which might implicates the participation of ER $\alpha$ in mediating endocrine resistance [22]. Thus, modulating of ER $\alpha$ expression and stability could be a promising strategy for breast cancer therapeutics and endocrine resistance.

Among hundreds of the E3 ubiquitin ligases, the members of the RING proteins attracted the attentions because of the uncommon ubiquitination members and the regulatory functions [23]. Unlike the classical E3 ligases, a proportion of RING family E3 ligases seem to preferentially catalyze atypical ubiquitinations, which does not link to protein degradation and turnover [24]. For example, RNF31 coupled with RBCK1 promote the linear ubiquitination of $\mathrm{IKKr}$ and facilitate NFKB signaling trans-activation [25, 26]. Recently studies reveal that 

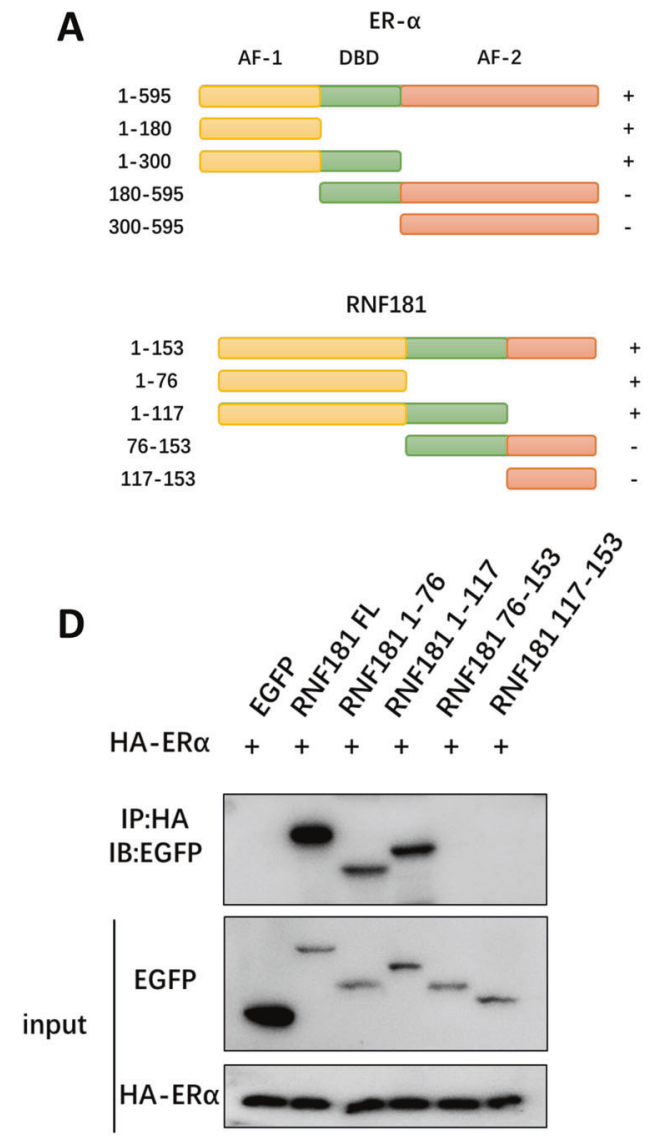

Fig. 6 RNF181 associates with AF1 domain of ERo through its RING domain. a ER $\alpha$ domain structure and deletion mutants were used in the study and RNF181 full length and deletion mutants were used in the study. $\mathbf{b}$ and $\mathbf{c}$ ER $\alpha$ interacts with RNF181 through its AF1 domain. HEK293 cells were transfected with $2 \mu \mathrm{g}$ Myc-RNF181 together with HA- ER $\alpha$ full length or mutants $(\Delta \mathrm{AF} 1, \Delta \mathrm{AF} 1+$ $\triangle \mathrm{DBD}, \triangle \mathrm{AF} 2$ and $\triangle \mathrm{AF} 2+\triangle \mathrm{DBD})$. After $24 \mathrm{~h}$, cells were treated with $10 \mathrm{uM}$ MG132 for $6 \mathrm{~h}$. Then the cells were harvested with NP-40 lysis buffer. CO-IP was performed using Myc antibody. The possible interacted $\mathrm{ER} \alpha$ domains were detected by HA antibody. d RING domain is required for RNF181 to interaction with ER $\alpha$. HEK293 cells

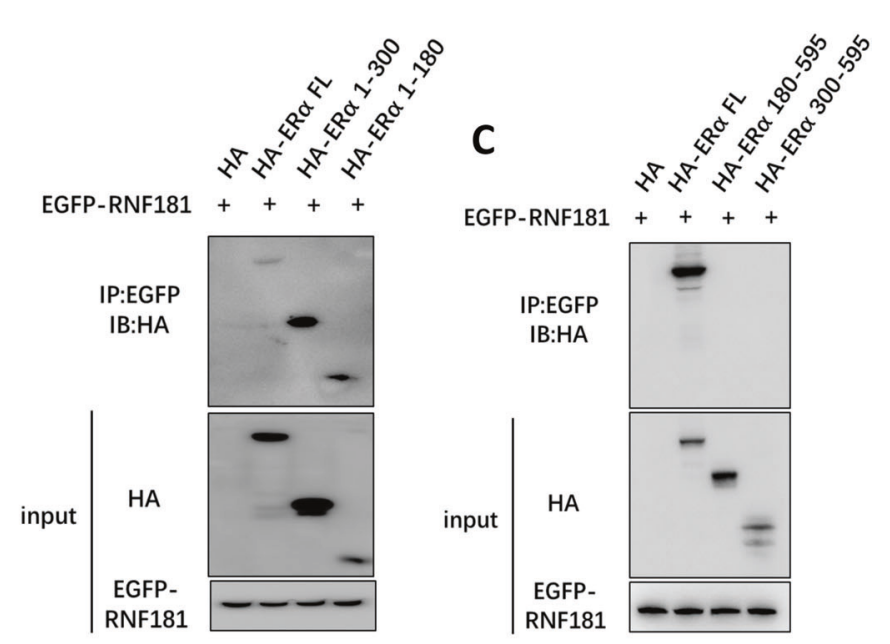

$\mathbf{E}$
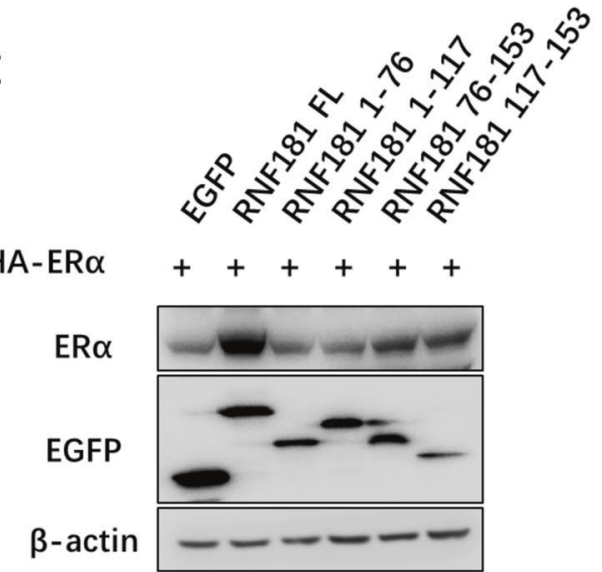

were transfected with $2 \mu$ g HA- ER $\alpha$ together with GFP-RNF181 full length or mutants $(\Delta \mathrm{N}$-terminal, $\Delta \mathrm{RING}+\Delta \mathrm{N}$-terminal, $\Delta \mathrm{C}$-terminal, $\Delta$ RING $+\Delta \mathrm{C}$-terminal). After $24 \mathrm{~h}$, cells were treated with $10 \mathrm{uM}$ MG132 for $6 \mathrm{~h}$. Then the cells were harvested with NP-40 lysis buffer. CO-IP was performed using HA antibody. The possible interacted RNF181 domains were detected by GFP antibody. e The intact RNF181 protein is require for its stabilization effect on ER $\alpha$. HEK293 cells were transfected with $2 \mu \mathrm{g}$ Flag- ER $\alpha$ and $0.5 \mu \mathrm{g}$ GFP-RNF181 full length or mutants $(\Delta \mathrm{N}$-terminal, $\Delta \mathrm{RING}+\Delta \mathrm{N}$-terminal, $\Delta \mathrm{C}$ terminal, $\Delta$ RING $+\Delta$ C-terminal). The $\mathrm{ER} \alpha$ protein levels were detected via western blotting analysis.

several RING family members participate in ER $\alpha$ signaling activation and breast cancer progression via nondegradation related ubiquitinations [27, 28]. For example, RNF31 could associate with ER $\alpha$, mono-ubiquitinate ER $\alpha$ and promote breast cancer proliferation [18]. Our previous studies identified a few E3 ubiquitin ligases in modulating $\mathrm{ER} \alpha$ signaling via either genomic regulations or posttranslational modifications, including TRIM56 and SMURF1 [27, 28]. In our current study, we uncover a novel regulatory mechanism between RNF181 and ER $\alpha$, which provides both novel knowledge of RNF family members in ER $\alpha$ function and a promising strategy for $\mathrm{ER} \alpha$ positive cancer therapeutics.
RNF181 belongs to the RING E3 ubiquitin ligase family, while the RING domain functions to catalyze the ubiquitin ligase reaction. RNF181 is critical for a few physiological functions [29]. For example, RNF181 functions to modulate integrin to facilitate platelet aggregation [30]. Interestingly, RNF181 is elevated in quite a few human cancers. RNF181 could interact with CARD11 and promote NKFB pathway in lymphoma [31]. Besides, RNF181 is also proved to facilitate colon cancer survival and angiogenesis [32]. Here, our data implicate that RNF181 is increased in human breast cancer and relates to poor outcome in endocrine therapy patients. RNF181 could promote breast cancer progression in vivo and in vitro and facilitate ER $\alpha$ 


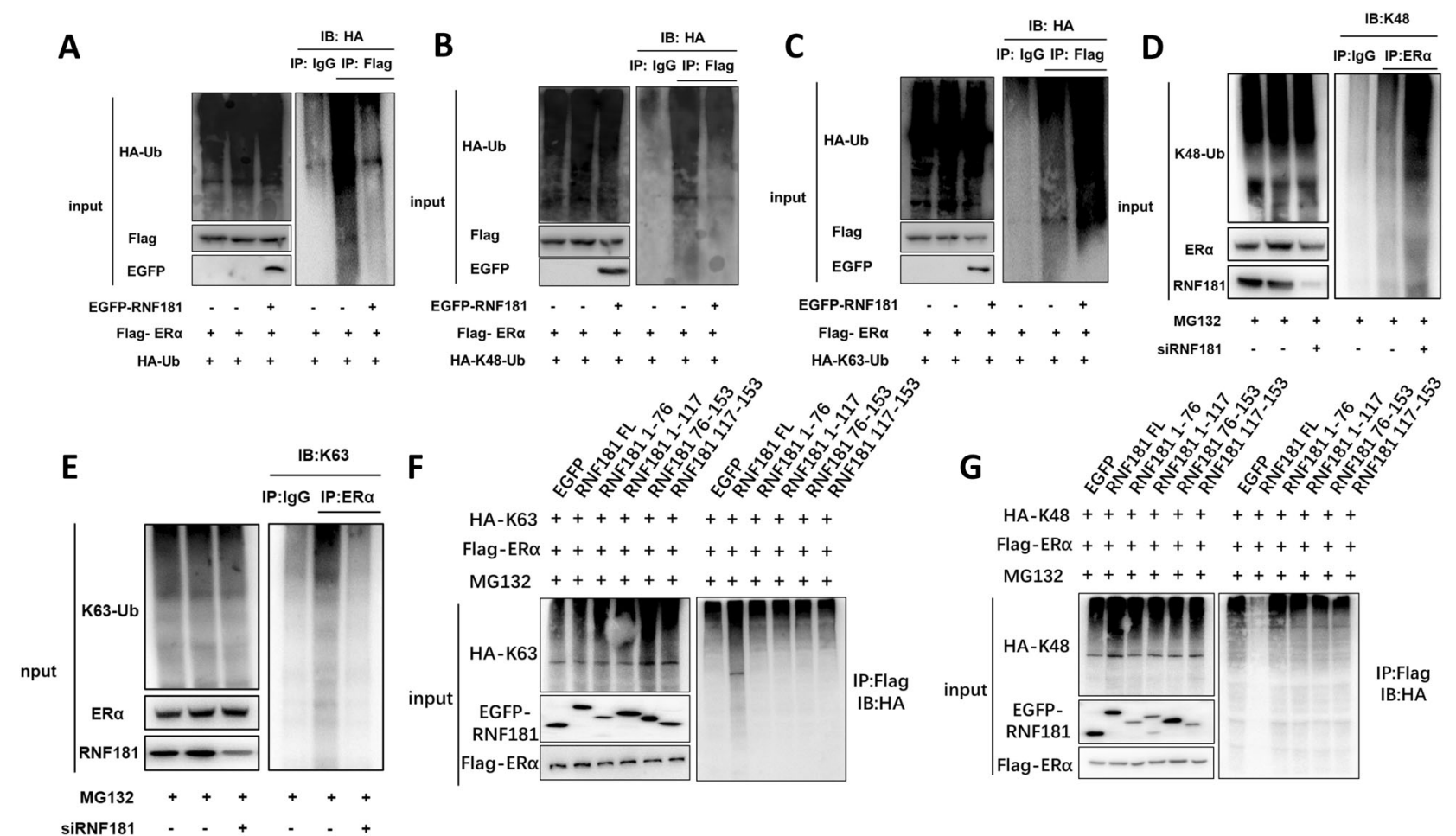

Fig. 7 RNF181 facilitates K63-linked poly-ubiquitination of ERo. a RNF181 decreases poly-ubiquitination of ER $\alpha$. HEK293 cells were transfected with $2 \mu \mathrm{g}$ ER $\alpha$ plasmid, $0.5 \mu \mathrm{g}$ HA Ub plasmid and $0.5 \mu \mathrm{g}$ Myc-tag or Myc-RNF181 plasmids. The cell extracts were immunoprecipitated with HA antibody. The poly-ubiquitinated ER $\alpha$ was detected via western blotting analysis. b RNF181 decreases K48linked poly-ubiquitination of ER $\alpha$. HEK293 cells were transfected with $2 \mu \mathrm{g}$ ER $\alpha$ plasmid, $0.5 \mu \mathrm{g}$ HA-K48 Ubi plasmid and $0.5 \mu \mathrm{g}$ Myctag or Myc-RNF181 plasmids. The cell extracts were immunoprecipitated with HA antibody. The K48 specific poly-ubiquitinated ER $\alpha$ was detected via western blotting analysis. c RNF181 promotes K63linked poly-ubiquitination of ER $\alpha$. HEK293 cells were transfected with $2 \mu \mathrm{g}$ ER $\alpha$ plasmid, $0.5 \mu \mathrm{g}$ HA-K63 Ubi plasmid and $0.5 \mu \mathrm{g}$ Myctag or Myc-RNF181 plasmids. The cell extracts were immunoprecipitated with HA antibody. The K63 specific poly-ubiquitinated ER $\alpha$ was detected via western blotting analysis. d RNF181 depletion increases endogenous K48-linked poly-ubiquitination of ER $\alpha$ in breast cancer cells. MCF-7 cells were transfected with $50 \mathrm{uM}$ siRNF181 siRNA or siControl. After $48 \mathrm{~h}$, cells were treated with MG132 for $6 \mathrm{~h}$. The cell extracts were immunoprecipitated with ER $\alpha$ antibody (D8H8, Cell signaling Technology). The K48 specific polyubiquitinated ER $\alpha$ was detected via K48 specific Ub antibody (A101,

signaling. Our study proves that RNF181 stabilizes ER $\alpha$ protein via a non-proteolytic ubiquitination manner, which provide a novel insight of the RING family protein in ER $\alpha$ signaling and breast cancer progression.

In conclusion, we identified an interesting E3 ligase RNF181 in facilitating ER $\alpha$ signaling in breast cancer cells. RNF181 could promote breast cancer cell invasion and proliferation via stabilizing ER $\alpha$ protein. As a novel modulator of ER $\alpha$ signaling, disturbing RNF181 activity or affecting RNF181 expression could be a plausible way to treat luminal types of breast cancer.
R\&D company). e RNF181 depletion inhibited endogenous K63linked poly-ubiquitination of ER $\alpha$ in breast cancer cells. MCF-7 cells were transfected with $50 \mathrm{uM}$ siRNF181 siRNA or siControl. After $48 \mathrm{~h}$, cells were treated with MG132 for $6 \mathrm{~h}$. The cell extracts were immunoprecipitated with ER $\alpha$ antibody (D8H8, Cell signaling Technology). The K63 specific poly-ubiquitinated ER $\alpha$ was detected via K63 specific Ub antibody (HWA404, Enzo life science). f The intact RNF181 protein is require for the inhibition of K48-linked poly-ubiquitination on ER $\alpha$. HEK293 cells were transfected with $2 \mu \mathrm{g}$ ER $\alpha$ plasmid, $0.5 \mu \mathrm{g}$ HA-K48 Ubi plasmid and $0.5 \mu \mathrm{g}$ GFP-RNF181 full length or mutants ( $\Delta \mathrm{N}$-terminal, $\Delta \mathrm{RING}+\Delta \mathrm{N}$-terminal, $\Delta \mathrm{C}$-terminal, $\Delta \mathrm{RING}+\Delta \mathrm{C}$-terminal) plasmids. The cell extracts were immunoprecipitated with HA antibody. The K48 specific poly-ubiquitinated $\mathrm{ER} \alpha$ was detected via western blotting analysis. $\mathbf{g}$ The intact RNF181 protein is require for the induction of K63-linked poly-ubiquitination on ER $\alpha$. HEK293 cells were transfected with $2 \mu \mathrm{g}$ ER $\alpha$ plasmid, $0.5 \mu \mathrm{g}$ HA-K63 Ubi plasmid and $0.5 \mu$ g GFP-RNF181 full length or mutants $(\Delta \mathrm{N}$-terminal, $\Delta \mathrm{RING}+\Delta \mathrm{N}$-terminal, $\Delta \mathrm{C}$-terminal, $\Delta \mathrm{RING}+\Delta \mathrm{C}$ terminal) plasmids. The cell extracts were immunoprecipitated with HA antibody. The K63 specific poly-ubiquitinated ER $\alpha$ was detected via western blotting analysis.

\section{Materials and methods}

\section{Cell culture}

MCF-7, T47D, and HEK293 cells are got from American Type Culture Collection (ATCC). T47D cells are cultured with RPMI-1640 (42401, Life Technologies) supplemented with $2 \mathrm{mM}$ L-glutamine (25030, Life Technologies) and 10\% FBS. MCF-7 and HEK293 are culture with Dulbecco's Modified Eagle's Medium that contains 4,5 g/L glucose and $4 \mathrm{mM}$ L-glutamine (DMEM, 41965, Life Technologies) 


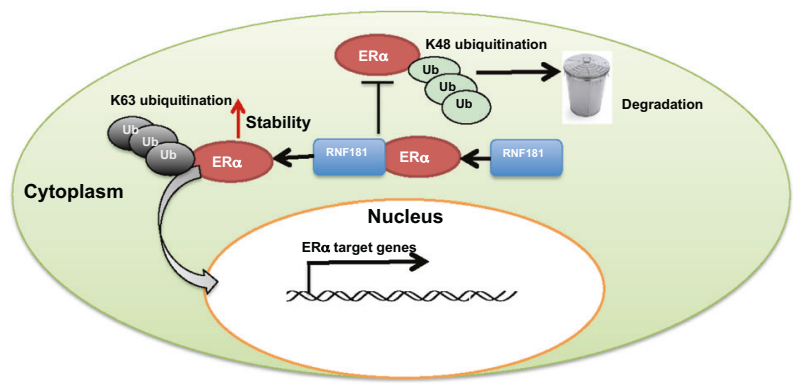

Fig. 8 The hypothesis model of RNF181 regulating ERo signaling in breast cancer. RNF181 interacts with ER $\alpha$ protein, stabilizes ER $\alpha$ and facilitates its signaling activation and breast cancer progression.

supplemented with 10\% Fetal Bovine Serum (FBS, 10270, Life Technologies). All cell lines are characterized by cell line authentication. The cell line authentication via Short Tandem Repeat (STR) is performed via PowerPlex 21 system. The STR data of MCF-7 and T47D cell lines are found consistent with STR data in ATCC.

\section{RNA extraction and qPCR analysis}

Total RNA was used to extract by RNeasy plus mini kits (Tiangen). Real-time PCR was showed as previously described [33]. 36B4 was used for internal reference. The primer sequences were displayed here. RNF181: F: cac aga cga gat aag gct cga a; R: tgg cca ggt ctg tga tca at. 36B4: F: ggc gac ctg gaa gtc caa ct; R: cca tca gca cca cag cct tc. GREB1 F: CGT GTG GTG ACT GGA GTA GC, R: ACC TCT TCA AAG CGT GTC GT. ER F: GCT ACG AAG TGG GAA TGA TGA AAG, R: TCT GGC GCT TGT GTT TCA AC. PS2 (TFF1) F: TGG GCT TCA TGA GCT CCT TC, R: TTC ATA GTG AGA GAT GGC CGG. The siRNA, shRNA and CRISPR g-RNA sequences were provided in supplementary table 1 .

\section{Quantification of cell viability}

MCF-7 and T47D cells were transfected with siRNF181 or siControl in 24-well plates. Twenty-four hours after transfection, the cells number was countered and 4000 cells were seeded into 96-well plates. The relative cell viability was measured at indicated time points. Cell numbers were determined using the WST-1 cell proliferation reagent as previously described [34].

\section{Wound healing assay}

Fifty nM RNF181 siRNA or siControl were transfected into MCF-7 cells. After twenty-four hours, cells were seeded into 12-well paltes with $1 \%$ FBS. The cells were $100 \%$ confluence. The yellow pipette tips were applied for straight scratch. The wound distance was measured at indicated time points and normalized with starting time point. The wound healing recovery was expressed as: [1-(Width of the wound at a given time/width of the wound at $t=0)] \times 100 \%$

\section{Clone formation assay}

MCF-7 were seeded in six-well plates overnight and treated with $50 \mathrm{nM}$ RNF181 siRNA or $50 \mathrm{nM}$ siControl. Twentyfour hours post-transfection, the cells were washed with PBS, trypsinized and plated at low density (5000 cell/well in six-well plate). The cells were cultured for 10 days and the medium was refreshed every 2 days. The colonies were stained with crystal violet. The number of the clones in a given area was counted for each condition.

\section{Xenograft tumor model}

MCF-7 cells were infected with shControl virus or shRNF181 virus. After $48 \mathrm{~h}$ of infection, cells were selected with $1 \mathrm{ug} / \mathrm{ml}$ puromycin for 3 days. The female nonobese diabetic-SCID mice were implanted with slow-relase 17 betaestradiol pellets $(0.72 \mathrm{mg} / 90$-day, Innovative Research of America). After $24 \mathrm{~h}$, about one million MCF-7 cells together with matrigel solution were injected into the mammary fat pad for each mouse. The tumor sizes were measured every 3 days. After 6 weeks, the mice were sacrificed and the tumors were weighted and photographed. The experiments were performed under the protocols approved by ethnic committee of Xinxiang Medical University.

\section{Western blotting}

Cells were harvested and lysed with RIPA buffer. Proteins were separated by electrophoresis on SDS-polyacrylamide gel electrophoresis (PAGE) and electro-transferred to PVDF membrane. The antibodies used in this study were listed here: Anti- ER $\alpha$ (D8H8, 8644, Cell signaling Technology); Anti- ER $\alpha$ (SC-56833, Santa Cruz); AntiRNF181 (SAB1401685, Sigma); Anti-HA (MMS-101R, COVANCE); Anti-myc (9E10, ab32, Abcam); Anti-myc (Ab9106, Abcam); RBCK1 (Ab108479, Abcam); AntiFlag (Ab49763, Abcam); Anti-GFP (Ab290, Abcam). Membranes were then washed with PBS for three times and incubated with secondary antibodies PeroxidaseConjugated AffiniPure Goat Anti-Mouse IgG or Goat Anti-Rabbit IgG. Fluorescent signals were visualized with ECL system (amersham imager 600, USA).

\section{Luciferase assay}

The luciferase activity of estrogen signaling activity was performed using the Dual-Luciferase Reporter kit (Promega, 
Germany). The ERE luciferase reporter was transfected together with the Renilla plasmid into the cells. Luciferase activity was measured after $24 \mathrm{~h}$.

\section{Co-immunoprecipitation assay}

Immunoprecipitation was performed as described in previous study [35]. The MCF-7 total cell lysls were precleared with rabbit $\operatorname{IgG}$ for $2 \mathrm{~h}$ and subsequently immunoprecipitated with ER $\alpha$ antibody (SC8005, Santa Cruz) overnight, while rabbit IgG (Santa Cruz) was used as the negative control. The bounded protein was analyzed by Anti-RNF181 (SAB1401685, Sigma). For the overexpression experiment, HEK293 cells were transfected with 5 ug GFP-RNF181 (Full length or deletion domains) and ER $\alpha$ plasmid (Full length or deletion domains) in $10 \mathrm{~cm}$ dish. Cell lysates were pre-cleared with IgG and subsequently incubate with GFP (Ab290, Abcam) antibody, while rabbit $\mathrm{IgG}$ was used as the negative control. The bound proteins were analyzed by western blotting.

\section{Poly-ubiquitination detection assay}

To directly detect the enriched overall ubiquitinated, K48linked or K63-linked ubiqutinated ER $\alpha$ from the cell extracts, HEK293 cells were transfected with 4 ug Ub, 4 ug K48 Ubi or 4 ug K63 Ubi plasmid, 2 ug ER $\alpha$ together with 0.5 ug Flag-RBCK1 or Flag-vector. After 48 h, cells were treated with $10 \mathrm{uM} \mathrm{MG132}$ and then the total protein was extracted and pre-cleared with $20 \mathrm{ul}$ protein A (santa cruz, SC-2001) for $2 \mathrm{~h}$. The supernatant was collected and immunoprecipitated by ER $\alpha$ antibody. Western blot with HA antibody was performed to detect K48 and K63 polyubiquitinated ER $\alpha$.

\section{Immunofluorescence assay}

MCF-7 cells were fixed with 4\% paraformaldehyde in PBS for $10 \mathrm{~min}$, permeabilized with $0.2 \%$ Triton X-100 for $5 \mathrm{~min}$, and blocked by 5\% BSA in PBS for $1 \mathrm{~h}$. A rabbit Anti-RNF181 (SAB1401685, Sigma) rabbit antibody and mouse anti-ER $\alpha$ monoclonal antibody (SC-56833) were used, followed by Alexa Flour 647 (Invitrogen) anti-rabbit antibody and FITC-conjugated anti-mouse antibodies (Jackson ImmunoResearch, West Grove, PA). As negative controls, the samples were incubated with the secondary antibodies without primary antibodies. Images were acquired under conditions fulfilling the Nyquist criterion using Nikon A + laser scanning confocal system with a 60X oil NA1.4 objective and pinhole size of 1.0 Airy Unit. The acquired pictures were further processed and assembled using ImageJ.

\section{Clinical breast tumor samples}

One hundred and twenty formalin-fixed paraffin-embedded breast cancer samples were collected from the Department of Pathology, Shandong Qilu Hospital. All the breast tumors samples were examined by ER $\alpha$ status, PR status, HER2 status by pathological specialists. The pathological grade plus lymph node metastasis status of each sample was also examined by pathological specialists. This study was reviewed and approved by the Ethical Board at the Qilu Hospital of Shandong University with written informed consent from all the patients.

\section{RNA sequence analysis}

The global gene expression analysis (siControl and siRNF181) was based on RNA sequencing platform from BGI (Beijing Genomic Institute). The RNA sequence data are deposited in the Gene Expression Omnibus database (Assessing number: GSE143947). Analysis was performed for differentially expressed genes $(P<0.01$ and fold change $>2$ ) by Ingenuity Pathway Analysis (IPA).

\section{Statistics}

Student's $t$ test, Pearson correlation coefficient, and Cox regression analysis were used for comparisons. A $P$ value of $<0.05$ was considered to be significant.

Acknowledgements We thank all the members of the Department of General Surgery in Second Hospital of Shandong University for sharing valuable material and research support.

Funding The project was supported from Joint Fund of the National Natural Science Foundation of China (No.U1604190, JZ), The KISDU joint research program for 2020, and the Key R\&D programs in Shandong Province (2019gsf108229, YD).

Author contributions JZ, XL and MX performed most of the bench work. JZ and YD supervised the process of the study and performed the paper writing. PS performed the xenograft mice study and IHC data analysis. YZ performed the RNA-sequence data analysis. All authors read and approve the final paper. JZ did most of the lab work and paper writing. XL and MX participated in the molecular biology work. PS performed the in vivo study and IHC data analysis. YZ did the RNA sequencing data analysis. YD offered financial support for this study and supervised the whole study.

\section{Compliance with ethical standards}

Conflict of interest The authors declare that they have no conflict of interest.

Ethical approval This study was reviewed and approved by the Ethical Board at Shandong University. This usage of clinical samples was reviewed and approved by the Ethical Board at the Qilu Hospital of 
Shandong University with written informed consents from all the patients.

Publisher's note Springer Nature remains neutral with regard to jurisdictional claims in published maps and institutional affiliations.

Open Access This article is licensed under a Creative Commons Attribution 4.0 International License, which permits use, sharing, adaptation, distribution and reproduction in any medium or format, as long as you give appropriate credit to the original author(s) and the source, provide a link to the Creative Commons license, and indicate if changes were made. The images or other third party material in this article are included in the article's Creative Commons license, unless indicated otherwise in a credit line to the material. If material is not included in the article's Creative Commons license and your intended use is not permitted by statutory regulation or exceeds the permitted use, you will need to obtain permission directly from the copyright holder. To view a copy of this license, visit http://creativecommons. org/licenses/by/4.0/.

\section{References}

1. Bray F, Ferlay J, Soerjomataram I, Siegel RL, Torre LA, Jemal A. Global cancer statistics 2018: GLOBOCAN estimates of incidence and mortality worldwide for 36 cancers in 185 countries. CA: Cancer J Clin. 2018;68:394-424. https://doi.org/10.3322/caac.21492

2. Cai, Z \& Liu, Q. Understanding the Global Cancer Statistics 2018: implications for cancer control. Sci China Life Sci. (2019). https:// doi.org/10.1007/s11427-019-9816-1

3. Onitilo AA, Engel JM, Greenlee RT, Mukesh BN. Breast cancer subtypes based on ER/PR and Her2 expression: comparison of clinicopathologic features and survival. Clin Med Res. 2009;7:4-13. https://doi.org/10.3121/cmr.2009.825

4. Vaz-Luis I, Ottesen RA, Hughes ME, Mamet R, Burstein HJ, Edge $\mathrm{SB}$, et al. Outcomes by tumor subtype and treatment pattern in women with small, node-negative breast cancer: a multiinstitutional study. J Clin Oncol. 2014;32:2142-50. https://doi. org/10.1200/JCO.2013.53.1608

5. Fan P, Jordan VC. New insights into acquired endocrine resistance of breast cancer. Cancer Drug Resist. 2019;2:198-209. https://doi.org/10.20517/cdr.2019.13

6. Jackisch C. Overcoming endocrine resistance in neoadjuvant endocrine therapy for early breast cancer. Lancet Oncol. 2019;20:1185-7. https://doi.org/10.1016/S1470-2045(19)30500-5

7. Lei JT, Anurag M, Haricharan S, Gou X, Ellis MJ. Endocrine therapy resistance: new insights. Breast. 2019;48:S26-30. https:// doi.org/10.1016/S0960-9776(19)31118-X

8. Greene GL, Gilna P, Waterfield M, Baker A, Hort Y, Shine J. Sequence and expression of human estrogen receptor complementary DNA. Science. 1986;231:1150-4. https://doi.org/10. 1126/science. 3753802

9. Renaud J, Bischoff SF, Buhl T, Floersheim P, Fournier B, Halleux $\mathrm{C}$, et al. Estrogen receptor modulators: identification and structureactivity relationships of potent ERalpha-selective tetrahydroisoquinoline ligands. J Med Chem. 2003;46:2945-57. https://doi.org/10.1021/jm030086h

10. Abdel-Magid AF. Selective Estrogen Receptor Degraders (SERDs): a promising treatment to overcome resistance to endocrine therapy in eralpha-positive breast cancer. ACS Med Chem Lett. 2017;8:1129-31. https://doi.org/10.1021/acsmedchemlett.7b00424

11. Renaud J, Bischoff SF, Buhl T, Floersheim P, Fournier B, Geiser $M$, et al. Selective estrogen receptor modulators with conformationally restricted side chains. Synthesis and structureactivity relationship of ERalpha-selective tetrahydroisoquinoline ligands. J Med Chem. 2005;48:364-79. https://doi.org/10.1021/ jm040858p

12. Ranganathan P, Nadig N, Nambiar S. Non-canonical estrogen signaling in endocrine resistance. Front Endocrinol. 2019;10:708. https://doi.org/10.3389/fendo.2019.00708

13. Wang C, Fu M, Angeletti RH, Siconolfi-Baez L, Reutens AT, Albanese C, et al. Direct acetylation of the estrogen receptor alpha hinge region by $\mathrm{p} 300$ regulates transactivation and hormone sensitivity. J Biol Chem. 2001;276:18375-83. https://doi.org/10. 1074/jbc.M100800200

14. Hanstein B, Eckner R, DiRenzo J, Halachmi S, Liu H, Searcy B, et al. p300 is a component of an estrogen receptor coactivator complex. Proc Natl Acad Sci USA. 1996;93:11540-5. https://doi. org/10.1073/pnas.93.21.11540

15. Bunone G, Briand PA, Miksicek RJ, Picard D. Activation of the unliganded estrogen receptor by EGF involves the MAP kinase pathway and direct phosphorylation. EMBO J. 1996;15:2174-83.

16. Metzger MB, Hristova VA, Weissman AM. HECT and RING finger families of E3 ubiquitin ligases at a glance. J Cell Sci. 2012;125:531-7. https://doi.org/10.1242/jcs.091777

17. Wang S, Luo H, Wang C, Sun H, Sun G, Sun N, et al. RNF8 identified as a co-activator of estrogen receptor alpha promotes cell growth in breast cancer. Biochimica et Biophysica Acta Mol Basis Dis. 2017;1863:1615-28. https://doi.org/10.1016/j.bbadis.2017.02.011

18. Zhu J, Zhao C, Kharman-Biz A, Zhuang T, Jonsson P, Liang N, et al. The atypical ubiquitin ligase RNF31 stabilizes estrogen receptor alpha and modulates estrogen-stimulated breast cancer cell proliferation. Oncogene. 2014;33:4340-51. https://doi.org/10. 1038/onc.2013.573

19. Shaaban AM, Sloane JP, West CR, Foster CS. Breast cancer risk in usual ductal hyperplasia is defined by estrogen receptor-alpha and Ki-67 expression. Am J Pathol. 2002;160:597-604. https:// doi.org/10.1016/s0002-9440(10)64879-1

20. Ali S, Coombes RC. Estrogen receptor alpha in human breast cancer: occurrence and significance. J Mammary Gland Biol Neoplasia. 2000;5:271-81. https://doi.org/10.1023/a:1009594727358

21. Musgrove EA, Sutherland RL. Biological determinants of endocrine resistance in breast cancer. Nat Rev Cancer. 2009;9:631-43. https://doi.org/10.1038/nrc2713

22. Haque MM, Desai KV. Pathways to endocrine therapy resistance in breast cancer. Front Endocrinol. 2019;10:573. https://doi.org/ 10.3389/fendo.2019.00573

23. Eisenhaber B, Chumak N, Eisenhaber F, Hauser MT. The ring between ring fingers (RBR) protein family. Genome Biol. 2007;8:209. https://doi.org/10.1186/gb-2007-8-3-209

24. Deshaies RJ, Joazeiro CA. RING domain E3 ubiquitin ligases. Annu Rev Biochem. 2009;78:399-434. https://doi.org/10.1146/a nnurev.biochem.78.101807.093809

25. Ikeda F, Deribe YL, Skanland SS, Stieglitz B, Grabbe C, FranzWachtel $\mathrm{M}$, et al. SHARPIN forms a linear ubiquitin ligase complex regulating NF-kappaB activity and apoptosis. Nature. 2011;471:637-41. https://doi.org/10.1038/nature09814

26. Tokunaga F, Nakagawa T, Nakahara M, Saeki Y, Taniguchi M, Sakata S, et al. SHARPIN is a component of the NF-kappaBactivating linear ubiquitin chain assembly complex. Nature. 2011;471:633-6. https://doi.org/10.1038/nature09815

27. Xue M, Zhang K, Mu K, Xu J, Yang H, Liu Y, et al. Regulation of estrogen signaling and breast cancer proliferation by an ubiquitin ligase TRIM56. Oncogenesis. 2019;8:30. https://doi.org/10.1038/ s41389-019-0139-x

28. Yang H, Yu N, Xu J, Ding X, Deng W, Wu G, et al. SMURF1 facilitates estrogen receptor a signaling in breast cancer cells. J Exp Clin Cancer Res. 2018;37:24. https://doi.org/10.1186/s13046-018-0672-z

29. Raab M, Daxecker H, Edwards RJ, Treumann A, Murphy D, Moran N. Protein interactions with the platelet integrin alpha(IIb) 
regulatory motif. Proteomics. 2010;10:2790-2800. https://doi.org/ 10.1002/pmic.200900621

30. Brophy TM, Raab M, Daxecker H, Culligan KG, Lehmann I, Chubb AJ, et al. RN181, a novel ubiquitin E3 ligase that interacts with the KVGFFKR motif of platelet integrin alpha(IIb)beta3. Biochemical Biophysical Res Commun. 2008;369:1088-93. https://doi.org/10.1016/j.bbrc.2008.02.142

31. Pedersen SM, Chan W, Jattani RP, Mackie d,S, Pomerantz JL. Negative Regulation of CARD11 Signaling and Lymphoma Cell Survival by the E3 Ubiquitin Ligase RNF181. Mol Cell Biol. 2015;36:794-808. https://doi.org/10.1128/MCB.00876-15

32. Jin $\mathrm{H}$, Cheng X, Pei Y, Fu J, Lyu Z, Peng H, et al. Identification and verification of transgelin- 2 as a potential biomarker of tumor-derived lung-cancer endothelial cells by comparative proteomics. J Proteom. 2016;136:77-88. https://doi.org/10.1016/j.jprot.2015.12.012

33. Liu Z, Zhang J, Xu J, Yang H, Li X, Hou Y, et al. RNF168 facilitates oestrogen receptor a transcription and drives breast cancer proliferation. J Cell Mol Med. 2018;22:4161-70. https:// doi.org/10.1111/jcmm.13694

34. Yang H, Yu S, Wang W, Li X, Hou Y, Liu Z, et al. SHARPIN Facilitates p53 degradation in breast cancer cells. Neoplasia. 2017;19:84-92. https://doi.org/10.1016/j.neo.2016.12.002

35. Zhuang T, Yu S, Zhang L, Yang H, Li X, Hou Y, et al. SHARPIN stabilizes estrogen receptor alpha and promotes breast cancer cell proliferation. Oncotarget. 2017;8:77137-51. https://doi.org/10. 18632/oncotarget.20368 